Article

\title{
Comprehensive Traffic Calming as a Key Element of Sustainable Urban Mobility Plans-Impacts of a Neighbourhood Redesign in Ljutomer
}

\author{
Mojca Balant ${ }^{1, *}$ and Marjan Lep ${ }^{2}$ \\ 1 Urban Planning Institute of the Republic of Slovenia, 1000 Ljubljana, Slovenia \\ 2 The Faculty of Civil Engineering, Transportation Engineering and Architecture, University of Maribor, \\ 2000 Maribor, Slovenia; marjan.lep@um.si \\ * Correspondence: mojcab@uirs.si
}

Received: 31 August 2020; Accepted: 28 September 2020; Published: 2 October 2020

\begin{abstract}
Negative impacts of motor vehicle traffic in cities are still increasing despite the objectives that sustainable mobility paradigm put forward almost three decades ago. Measures to reduce them still primarily focus on traffic safety improvements through vehicle speeds and flows reduction (traffic calming). Comprehensive traffic calming, a measure of sustainable urban mobility planning, targets the issue more comprehensively by also addressing changes in travel behaviour and quality of life. Literature covering the effects of measures addressing all listed aspects is scarce. In this paper, we present results of a longitudinal study of a comprehensive traffic calming redesign of a residential neighbourhood in Ljutomer in Slovenia. The following set of indicators was monitored: travel habits of neighbourhood residents, quality of living environment, acceptability of redesign, vehicle flows, speeds and classes, and traffic accidents. Motorized traffic counts, pilot interviews, postal and in-person surveys and public databases on traffic accidents were used to gather data before and after the redesign. All monitored indicators showed positive results. Around a third of residents claim to walk, cycle and socialize more than before the redesign while around two thirds state that the quality of life in the neighbourhood has improved. Vehicle speeds, flows and peak hour flows have notably decreased, and road safety has improved. The results show that the comprehensive traffic calming approach has a broad range of positive effects and contributes to achieving sustainable mobility. Its potential for a wider use in sustainable urban mobility planning practice is substantial.
\end{abstract}

Keywords: comprehensive traffic calming; active mobility; travel behaviour; quality of life; traffic safety; sustainable urban mobility planning; sustainable urban mobility plan; SUMP

\section{Introduction}

In recent years, sustainable urban mobility planning (SUM planning) has become increasingly established as a new approach for transport planning and mobility management in urban areas in a sustainable and comprehensive way. It follows the principles of the overarching sustainable mobility paradigm whose purpose is "to design cities of such quality and at a suitable scale that people would not need to have a car" [1] (p. 74). The paradigm also promotes the new transport hierarchy [1,2] from which the SUM planning takes its objectives of improving accessibility, quality of life and traffic safety, and increasing the use of sustainable travel modes. The latter are also objectives for urban mobility at the European level [3,4]. SUM planning approach is used for the preparation of Sustainable Urban Mobility Plans (SUMP), a strategic document that builds on existing planning practices while also considering integration, participation and evaluation principles [5]. The preparation and implementation of SUMPs is becoming a common practice in Europe and Slovenia in the last decade $[5,6]$. 
The development of a new paradigm of sustainable mobility is about thirty years old [7]. Its development has been stimulated by the constant increase in the volume of motorized traffic and, consequently, by its increasingly pronounced negative effects. While mobility has brought about positive economic and social effects, such as wealth, international collaboration, and exchange [8], there are also negative aspects including high proportion of urban land used by transport, urban sprawl, congestion, traffic noise, energy use and social and environmental problems [2,7-10]. Furthermore, major negative effects are mainly related to the private car [10]. Its intensive use has been proven to reduce the amount of physical activity, increase the possibility of traffic accidents, have a negative impact on health and the living environment and reduce the possibilities for social interaction [3,4,11-18].

Sustainable urban mobility planning addresses these challenges. Its main goal is to reduce the use of powered private vehicles. It focuses on sustainable travel modes, especially active mobility (walking and cycling), which is characterized by being the healthiest, least environmentally controversial, economically most rational and most socially equitable form of mobility [2,19-23]. These advantages make active mobility "the most favourable mode in terms of sustainability" [2] (p. 137) while it is also supported by other modern paradigms for creating green, healthy cities that are pleasant to live in $[24,25]$.

Achieving a notable increase in active mobility for daily trips requires a significant improvement of the conditions for walking and cycling by establishing a system of safe, comfortable, direct and attractive infrastructure $[23,26]$ and exclusive routes for pedestrians and cyclists [1]. Comprehensive traffic calming, a measure of SUM planning, is increasingly recognized as one of the more effective approaches. Its basic elements are larger set areas, most often in residential neighbourhoods, around schools and in city centres, where pedestrians and cyclists have priority. In addition to arrangements to reduce the speed and volume of motorized traffic aiming at improving traffic safety, the interventions also include the redesign of the public open space with the aim of improving the quality of living environment and changing travel habits into more sustainable ones. Several authors discuss the characteristics of this type of planning approach [9,18,27-33], and various older [34] and recent [35-40] examples of good practices from Northern and Western Europe are described. However, there is a lack of studies in the literature on the comprehensive quantified effects of (comprehensive) traffic calming on changing travel habits, traffic safety and quality of life [41-44].

The article presents the results of the comprehensive multi-year monitoring and evaluation of a pilot redesign of a residential neighbourhood in Ljutomer in Slovenia into an area with comprehensively calmed traffic. In 2014, 2017 and 2018 (before and after the redesign), the study systematically collected qualitative and quantitative data for the following indicators: travel habits of neighbourhood residents, quality of living environment, acceptability of redesign, vehicle flows, speeds and classes, and traffic accidents. The redesign of the neighbourhood was one of the measures of the first municipal SUMP [45], and the neighbourhood was in part also chosen because the municipality had already planned the renovation of underground municipal infrastructure and thus used the planned construction works for innovative improvement of traffic regulation. The redesign was carried out in line with the principles of SUM planning and followed the key steps for the preparation of the SUMP $[5,46]$. It is the first example of such a redesign and monitoring of effects in the country and the wider region. The importance of the study is even greater, as such a wide range of indicators is rarely measured for an individual measure [42].

\subsection{Intensive Car Use and Health Issues}

As pointed out above, intensive use of private car has been proven to reduce the amount of physical activity and has led to an increasingly sedentary life even when people essentially move around [47]. Consequently, this adds substantially to the general lack of physical activity, which has become one of the leading causes of death worldwide in recent years. As a key risk factor for non-communicable diseases, lack of physical activity claims more than a million premature deaths a year in Europe [17]. Comparatively, traffic accidents have a lower tax, but the numbers are still high. 
In Europe, more than 25,000 people die on the roads every year, and around 200,000 suffer serious injuries [13]. The data show that conventional approaches to traffic calming in urban areas, which focus mainly on reducing driving speeds and improving traffic safety, are not effective enough. In Europe, almost 8000 pedestrians and cyclists still die in traffic accidents each year, and more than 60,000 are seriously injured. Nearly two thirds of accidents involving pedestrians and cyclists occur on roads within urban areas [13]. Thus, with their high population densities and high share of short-distance trips, the cities have the greatest potential to move towards sustainable travel modes [3] and to achieve the European Union's ambitious goals of increasing the share of active mobility on daily routes, reducing the number of traffic accidents, and improving the quality of life [11].

\subsection{Pilot Neighbourhood Characteristics}

The Juršovka residential neighbourhood is part of Ljutomer (3400 inhabitants) in Slovenia (Figure 1). It comprises four streets with one transit central axis and three access streets. The streets are connected by several segregated footpaths. The longest route is less than a kilometre and a half from one end of the neighbourhood to the other. The area lies on hilly terrain facing south. The neighbourhood consists of single-family houses with 119 households and 352 inhabitants. The majority of the population is aged between 18 and 65 (66.8\%), 17.9\% are under 18 and 15.3\% are over 65 [48]. Prior to the redesign, the traffic regime restricted traffic with classic restrictions for settlements (permitted speeds of up to $50 \mathrm{~km} / \mathrm{h}$ ). Due to the small amount of traffic, no pavement was built in the neighbourhood, which bothered the residents, as individual drivers exceeded the speed limit and thus endangered pedestrians and cyclists. The area started experiencing parking on the road, which did not obstruct traffic, but was disruptive. Pedestrian connections were not maintained or lit.

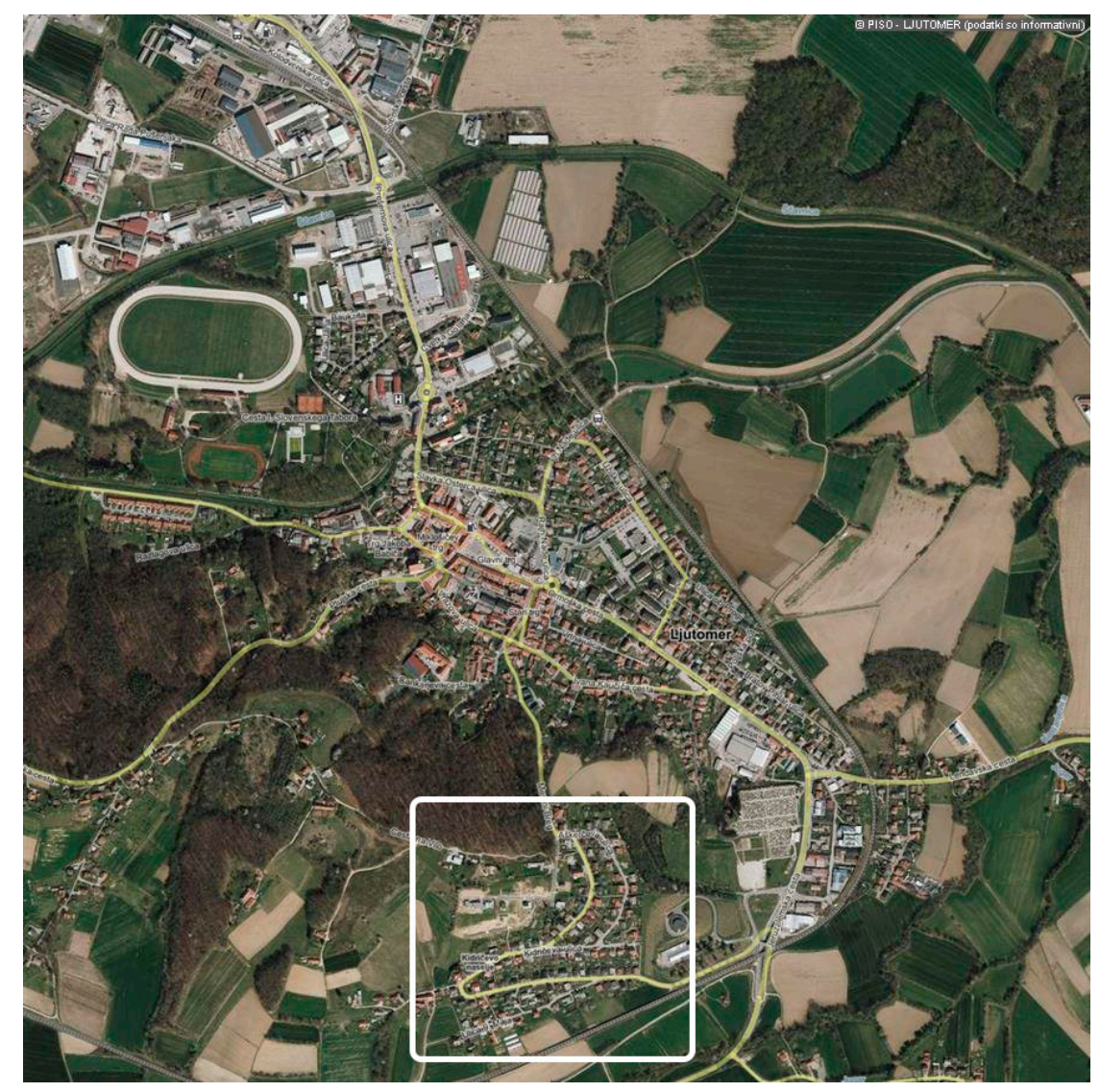

Figure 1. The settlement of Ljutomer with the marked residential neighbourhood of Juršovka (Source of background picture: www.geoprostor.net). 
With the comprehensive traffic calming, the neighbourhood was redesigned in terms of traffic arrangements and public open space. A different traffic regime was introduced, and new, quality public spaces were set up (Figure 2). The redesign was based on twelve typical elements: $30 \mathrm{~km} / \mathrm{h}$ speed limit on the main (transit) street and $10 \mathrm{~km} / \mathrm{h}$ on the side (access) streets; cycling without designated bicycle lanes due to low speeds; pavement on one side along the main street; renovation and lighting of the segregated footpaths; parking allowed only in marked places; setting up areas for socialising with benches and other urban equipment and playground equipment; plantings with trees, shrubs and perennials; traffic calming by converting intersections into mini roundabouts; traffic calming by a speed hump at the point of contact of the footpath with the road; traffic calming by narrowing the carriageway with combinations of plantings, planters, benches, playground equipment and parking spaces; traffic calming by narrowing entry points to the neighbourhood.
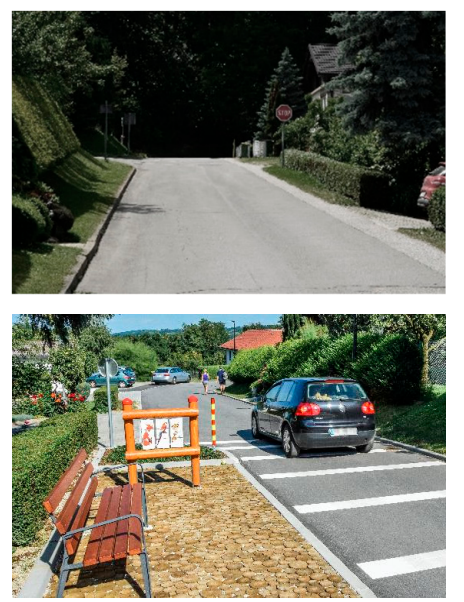

(a)
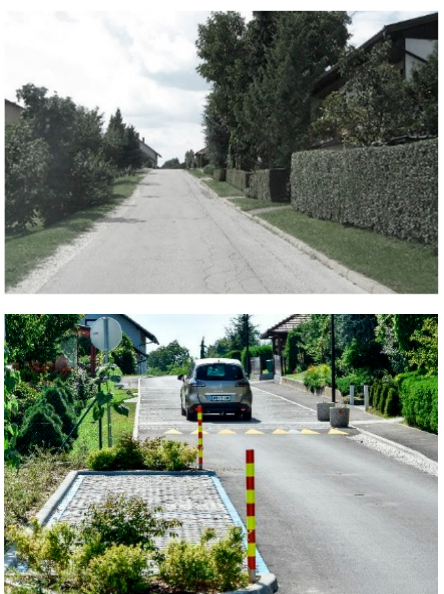

(b)
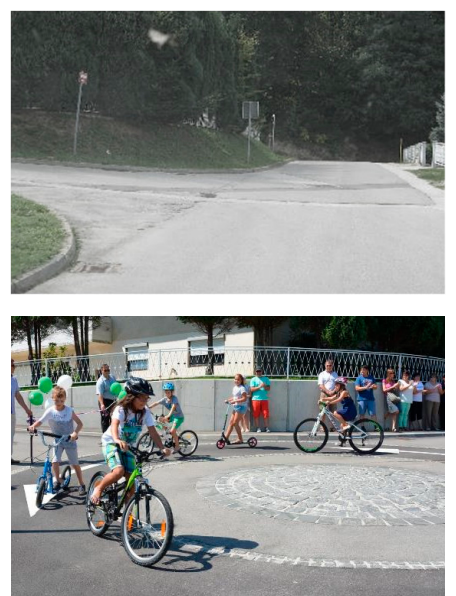

(c)

Figure 2. Three examples of the redesign elements showing the same locations before and after the redesign: (a) traffic calming by narrowing the carriageway with benches, playground equipment and plantings; (b) traffic calming by narrowing the carriageway with parking spaces and plantings and (c) traffic calming by converting intersections into mini roundabouts.

\section{Materials and Methods}

The effects of comprehensive traffic calming in the Juršovka neighbourhood in Ljutomer were analysed using empirical research, namely through surveys, pilot interviews, time series analysis and analysis of data in public databases. Data were collected before and after the redesign of the neighbourhood, which took place in 2016 and was completed in July 2016.

The survey and pilot interviews were used to identify changes in the travel habits of neighbourhood residents. The survey was also used to determine the acceptability of the redesign of the neighbourhood into an area of comprehensively calmed traffic and changes in the perceived quality of the living environment. We conducted surveys and interviews in 2014 and 2017. The pilot interviews were conducted on 22 May 2014 as part of the preparation of a conceptual project neighbourhood redesign [48]. We interviewed 10 households ( $8 \%$ ), which were selected on the basis of demographic and spatial analysis. The selection ensured an even representation of age groups $(0-18,18-65$ and over 65 years of age) and the distribution of interviewees throughout the neighbourhood. The first survey was conducted in June 2014, following a workshop on the conceptual design of the neighbourhood redesign and as part of the preparation of a conceptual project for neighbourhood redesign [48]. It was sent to all households and was completed by 30 households (25\%). The survey was simple and short, its key part was a questionnaire about the support of the proposed typical redesign elements. Respondents rated individual elements using a three-point scale. The second survey was conducted in June and July 2017 as part of the activities of the European project Civitas Prosperity [49]. The survey was 
delivered in person to all 119 households in the neighbourhood and was completed by 85 households (71\%). The survey was longer and more complex; we collected data on changes in travel habits and the quality of the living environment, as well as responses to typical redesign elements and the redesigned neighbourhood as a whole. Respondents rated the answers using a five-point scale. We used time series analysis to determine changes in vehicle flows, speeds and classes in three-time sections. The situation before the redesign was recorded on 17 June 2014 [50], and the situation one and two years after the redesign was recorded on 6 July 2017 [51] and 26 September 2018 [52]. Data from public databases were used to determine the number and consequences of traffic accidents in the neighbourhood and in the settlement of Ljutomer. We obtained them from the statistical files of the National Police containing data on all traffic accidents in Slovenia for the period 2000-2019 [53].

\subsection{Travel Habits of Neighbourhood Residents}

Data on the travel habits of neighbourhood residents were collected through pilot interviews (2014) and a household survey (2017). We were mainly interested in the use of active mobility (walking and cycling) on daily routes. The interviewees specified for the whole household the use of travel modes for different daily routes (to work, running errands, to school and to/for recreation) and the reasons for not using walking and cycling on daily routes. Respondents to the survey specified for three age groups within an individual household (0-18, 18-65 and over 65 years of age), using a five-point response scale, the more frequent use of walking and cycling on daily routes after the redesign and the contribution of individual elements of the redesign to the facilitation of walking and cycling.

\subsection{Quality of Living Environment}

Data on the quality of the living environment in the neighbourhood after the redesign were collected through a household survey (2017). Using a five-point response scale, respondents rated the improvement of the overall quality of life in the neighbourhood, the frequency of staying outside and socialising with neighbours after the redesign and the contribution of each redesign element to improving the quality of living environment.

\subsection{Acceptability of the Redesign}

Data on the acceptability of the redesign of the neighbourhood into an area of comprehensively calmed traffic were collected through household surveys (2014 and 2017). In the first survey, respondents rated nine proposed typical redesign elements using a three-point response scale. The part of the second survey relating to the acceptability of the redesign encompassed twelve redesign elements that were actually used, including all elements from the first survey. Respondents rated their support for each typical redesign element using a five-point response scale and, according to the characteristics of each element, an appropriate set of the following categories: understandability, compliance with the regime, use, impact on traffic calming. They could also list the parts of the redesign they liked most and least.

\subsection{Vehicle Flows and Speeds}

All three-time sections of motorized traffic measurements are data obtained at the same four locations within the neighbourhood. Three measuring locations were on the main (transit) street through the neighbourhood, one of which was at the entrance point to the neighbourhood, and one measuring location was on a side (access) street. Data were collected for the needs of the research work of the group for sustainable mobility from the Urban Planning Institute of the Republic of Slovenia, Ljubljana, Slovenia. The measurements were carried out by the Centre for Mobility Research from the Faculty of Civil Engineering, Transportation Engineering and Architecture of the University of Maribor, Maribor, Slovenia. Measurements were performed on a working day with automatic pneumatic traffic counters. Daily $(24 \mathrm{~h})$ two-way vehicle flows, speeds and classes were measured at all four measuring locations. 


\subsection{Traffic Safety}

We were interested in traffic accidents in the area of the Juršovka neighbourhood and comparatively in the entire settlement of Ljutomer. For Ljutomer, we obtained data on the number of accidents, number of participants and serious consequences (severe injury or death, type of participant). We obtained some more detailed data for the neighbourhood (all types of consequences, including material damage and minor injury, cause and type of accident, type of participant, location of the accident (street)).

\section{Results}

\subsection{Travel Habits of Neighbourhood Residents}

\subsubsection{Travel Habits of Neighbourhood Residents Before Redesign}

Most residents use a car for daily trips to work and school and for running errands (80\%); walking and cycling are rarely chosen (15\% and $4 \%$, respectively) and are used most often for running errands ( $23 \%$ on foot, $6 \%$ by bicycle). For most people, walking and cycling are a form of afternoon recreation ( $56 \%$ of them walk and $32 \%$ cycle recreationally or to get to recreation).

The most cited reasons for the infrequent use of walking and cycling for daily trips were lack of time (e.g., they run errands by car so they have more time for afternoon recreation in nature), the dangerous route through the settlement, especially for children (no pavement, excessive speeds, dangerous intersections, obstructed views of the road), long distances, sloped terrain and the fact that it is not common to take daily trips on foot or by bicycle.

\subsubsection{Travel Habits of Neighbourhood Residents after Redesign}

The use of walking and cycling for daily routes was significantly higher one year after the redesign of the neighbourhood (Table 1). 37\% of the population walk more often (18\% a lot and $19 \%$ a little more often), $27 \%$ cycle more often ( $15 \%$ a lot and $12 \%$ a little more often). After the redesign, $2 \%$ walk less often and $11 \%$ cycle less often, while $61 \%$ walk and cycle the same as before the redesign. The frequency of walking and cycling increased the most among children and youth (0-18 years); $40 \%$ walk more often ( $10 \%$ a lot and $30 \%$ a little more often), $36 \%$ cycle more often ( $18 \%$ a lot and $18 \%$ a little more often). They are followed by adults (18-65 years); $39 \%$ walk more often ( $21 \%$ a lot and $18 \%$ a little more often), and $31 \%$ cycle more often ( $16 \%$ a lot and $15 \%$ a little more often). The smallest increase in the use of walking and cycling was reported by the elderly (over 65 years); $30 \%$ of them walk more often ( $15 \%$ a lot and $15 \%$ a little more often), and only $8 \%$ cycle more often ( $8 \%$ a lot and $0 \%$ a little more often).

Table 1. Frequency of walking and cycling after redesign of the neighbourhood by individual age groups.

\begin{tabular}{|c|c|c|c|c|c|c|}
\hline $\begin{array}{l}\text { Travel } \\
\text { Mode }\end{array}$ & Age Group & $\begin{array}{l}\text { YES, Very } \\
\text { Often }\end{array}$ & $\begin{array}{l}\text { YES, Quite } \\
\text { Often }\end{array}$ & $\begin{array}{l}\text { YES, a Little } \\
\text { More Often }\end{array}$ & $\begin{array}{c}\text { Same as } \\
\text { Before }\end{array}$ & $\begin{array}{c}\text { NO, Less } \\
\text { Often }\end{array}$ \\
\hline \multirow{4}{*}{ Walking } & All & $13 \%$ & $4 \%$ & $19 \%$ & $61 \%$ & $2 \%$ \\
\hline & Children and youth (up to age 18 ) & $10 \%$ & $0 \%$ & $30 \%$ & $60 \%$ & $0 \%$ \\
\hline & Adults (ages 18-65) & $15 \%$ & $6 \%$ & $18 \%$ & $59 \%$ & $3 \%$ \\
\hline & Elderly (over 65) & $12 \%$ & $4 \%$ & $15 \%$ & $69 \%$ & $0 \%$ \\
\hline \multirow{4}{*}{ Cycling } & All & $11 \%$ & $4 \%$ & $12 \%$ & $61 \%$ & $11 \%$ \\
\hline & Children and youth (up to age 18 ) & $14 \%$ & $5 \%$ & $18 \%$ & $55 \%$ & $9 \%$ \\
\hline & Adults (ages 18-65) & $12 \%$ & $4 \%$ & $15 \%$ & $60 \%$ & $9 \%$ \\
\hline & Elderly (over 65) & $4 \%$ & $4 \%$ & $0 \%$ & $72 \%$ & $20 \%$ \\
\hline
\end{tabular}

The majority of the population (58\%) believe that the redesign of the neighbourhood into an area of comprehensively calmed traffic encourages more frequent use of walking and/or cycling ( $25 \%$ disagree, $18 \%$ are undecided). According to residents, the following elements have the most positive impact: pavement along the main street through the neighbourhood (79\%); renovation of segregated footpaths 
$(77 \%) ; 30 \mathrm{~km} / \mathrm{h}$ speed limit on the main street $(62 \%)$; cycling without designated bicycle lanes due to low car speeds $(62 \%)$ and plantings with trees, shrubs and perennials (58\%).

\subsection{Quality of Living Environment}

The majority of the population (63\%) believe that the overall quality of life in the neighbourhood has significantly improved after the redesign, 19\% believe that it has not improved, and 19\% are undecided (Table 2). Elements of redesign that, according to residents, contributed the most to improving the overall quality of life in the neighbourhood are the pavement along the main street through the neighbourhood (87\%); renovation of footpaths (84\%); plantings with trees, shrubs and perennials (69\%); traffic calming by speed humps $(68 \%)$ and the $30 \mathrm{~km} / \mathrm{h}$ speed limit on the main street $(66 \%)$. Even for most of the remaining elements of the redesign, more than half of the population was of the opinion that they had contributed to improving the overall quality of life in the neighbourhood. The worst rated elements were the conversion of intersections into mini roundabouts ( $36 \%$ in favour and $39 \%$ against) and traffic calming by narrowing the carriageway on both entry points to the neighbourhood ( $49 \%$ in favour and $28 \%$ against).

Table 2. Change in overall quality of life after neighbourhood redesign.

\begin{tabular}{cccccc}
\hline & $\begin{array}{c}\text { I Strongly } \\
\text { Agree }\end{array}$ & Agree & $\begin{array}{c}\text { Neither Agree } \\
\text { nor Disagree }\end{array}$ & Disagree & $\begin{array}{c}\text { Strongly } \\
\text { Disagree }\end{array}$ \\
\hline $\begin{array}{c}\text { The redesign has improved the overall } \\
\text { quality of life in the neighbourhood }\end{array}$ & $25 \%$ & $38 \%$ & $19 \%$ & $10 \%$ & $9 \%$ \\
\hline
\end{tabular}

The frequency of staying outside and socialising with neighbours was substantially higher one year after the redesign of the neighbourhood (Table 3). Of the population, $28 \%$ spend more time outside and socialise with neighbours (14\% much and $14 \%$ a little more often), $3 \%$ less often, and the majority (69\%) the same as before the redesign. Adults (18-65 years) changed their habits the most. After redesign, just under a third (32\%) of them spend more time outside and socialise with neighbours. The share of the elderly (over 65 years) is $26 \%$, and among children and youth (0-18 years), it is $19 \%$. The majority maintained their habits ( $64 \%$ of adults, $74 \%$ of the elderly and $81 \%$ of children and youth), and only $4 \%$ of adults reported less frequent stays outside and socialising with neighbours after the redesign.

Table 3. Changes in the frequency of staying outside and socialising with neighbours after neighbourhood redesign by individual age groups.

\begin{tabular}{|c|c|c|c|c|c|c|}
\hline & & $\begin{array}{l}\text { YES, Very } \\
\text { Often }\end{array}$ & $\begin{array}{l}\text { YES, Quite } \\
\text { Often }\end{array}$ & $\begin{array}{l}\text { YES, Somewhat } \\
\text { More Often }\end{array}$ & $\begin{array}{l}\text { Same as } \\
\text { Before }\end{array}$ & $\begin{array}{l}\text { NO, Less } \\
\text { Often }\end{array}$ \\
\hline \multirow{3}{*}{$\begin{array}{l}\text { Staying outside } \\
\text { and socialising } \\
\text { with neighbours }\end{array}$} & All & $8 \%$ & $7 \%$ & $14 \%$ & $69 \%$ & $3 \%$ \\
\hline & $\begin{array}{l}\text { Children and youth } \\
\text { (up to age 18) }\end{array}$ & $5 \%$ & $5 \%$ & $10 \%$ & $81 \%$ & $0 \%$ \\
\hline & Adults (ages 18-65) & $9 \%$ & $6 \%$ & $17 \%$ & $64 \%$ & $4 \%$ \\
\hline
\end{tabular}

\subsection{Acceptability of the Redesign}

\subsubsection{Acceptability of the Redesign, before Redesign}

On average, almost four fifths of the population (78\%) expressed support for the proposed typical redesign elements, $8 \%$ of the population expressed partial support and $14 \%$ opposed the changes. Four of the nine redesign elements received very high levels of support with negligible opposition, while the other half received the support of more than half of the population, but also opposition from at least a fifth. 
A very high level of support was given to the pavement along the main street through the neighbourhood (100\% in favour), traffic calming at $30 \mathrm{~km} / \mathrm{h}$ on the main street $(90 \%$ in favour and $0 \%$ against), cycling without designated bicycle lanes due to low car speeds ( $90 \%$ in favour and $7 \%$ against) and side streets without raised pavements ( $83 \%$ in favour and $7 \%$ against). The least support was given to traffic calming by narrowing of the carriageway with plantings, benches, playground equipment or parking spaces (57\% in favour and $32 \%$ against) and traffic calming at $10 \mathrm{~km} / \mathrm{h}$ on side streets (65\% in favour and $28 \%$ against); these were followed by parking only in marked places in the neighbourhood (63\% in favour and $20 \%$ against) and converting intersections into mini roundabouts (72\% in favour and $21 \%$ against).

\subsubsection{Acceptability of the Redesign, after Redesign}

Support for the typical redesign elements remained high. On average, three quarters of the population (75\%) agree with the new neighbourhood layout, $15 \%$ oppose it, and $10 \%$ are undecided. Of the twelve typical redesign elements used, five received very high levels of support with little opposition, six received support from more than half of the population but in some cases received increased opposition, and one element was rated very negatively (Figure 3).

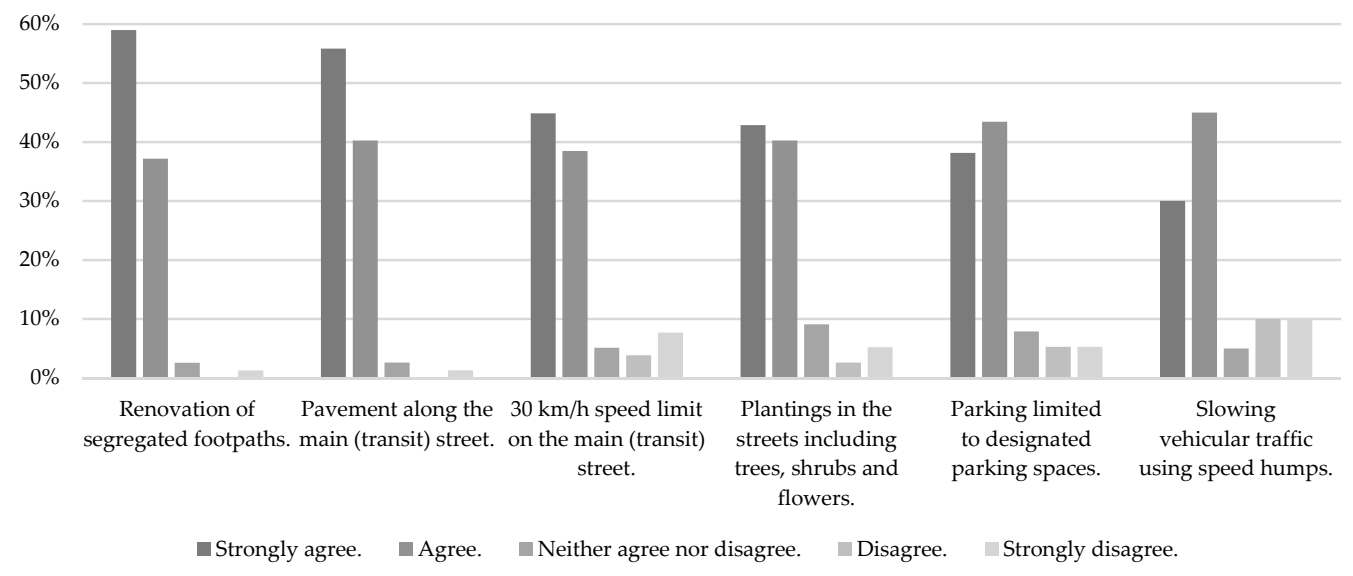

(a)

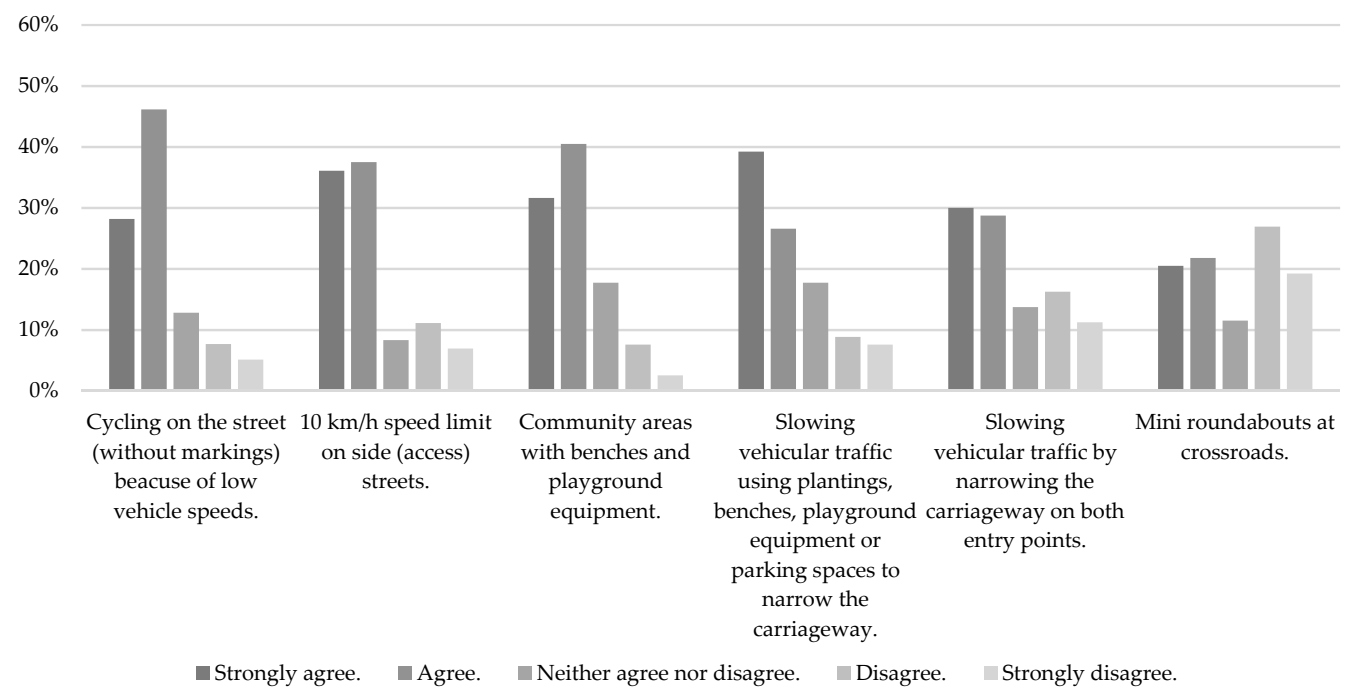

(b)

Figure 3. Rating of acceptability among the population for all twelve typical elements of redesign from the element with the most support to the one with the least support; (a) elements with more support and (b) elements with less support. 
Very high levels of support were given to the building of the pavement along the main street through the neighbourhood ( $93 \%$ in favour and 1\% against), the renovation of the footpaths in the neighbourhood (93\% in favour and $1 \%$ against), traffic calming at $30 \mathrm{~km} / \mathrm{h}$ on the main street $(83 \%$ in favour and $12 \%$ against), plantings with trees, shrubs and perennials ( $83 \%$ in favour and $8 \%$ against) and parking only in marked places in the neighbourhood ( $82 \%$ in favour and $11 \%$ against). The least support was given to the conversion of intersections into mini roundabouts ( $42 \%$ in favour and $46 \%$ against). The remaining elements of the redesign were supported by $59 \%$ to $75 \%$ of the population, while $13 \%$ to $28 \%$ of the population opposed them. From more to less acceptable are traffic calming by speed humps (75\% in favour and $20 \%$ against), cycling without designated bicycle lanes due to low car speeds (74\% in favour and $13 \%$ against), traffic calming at $10 \mathrm{~km} / \mathrm{h}$ on side streets $(74 \%$ in favour and $18 \%$ against), community areas with benches and arrangements for playing ( $72 \%$ in favour and $10 \%$ against), traffic calming with plantings, benches, playground equipment or parking spaces used to narrow the carriageway (66\% in favour and $16 \%$ against) and traffic calming with narrowing at both entry points to the neighbourhood (59\% in favour and $28 \%$ against).

Understandability was rated for limiting driving speed and mini roundabouts. Mini roundabouts proved to be problematic, with $43 \%$ of the population saying they were incomprehensible (comprehensible for $41 \%, 16 \%$ undecided). They were also by far the most frequently mentioned among the least likeable parts of the redesign. The speed limit is understandable to most residents (79\% for $30 \mathrm{~km} / \mathrm{h}$ and $70 \%$ for $10 \mathrm{~km} / \mathrm{h}$ ).

Adherence to the regime was rated for speed limit and parking. Residents claim that $96 \%$ adhere to the $30 \mathrm{~km} / \mathrm{h}$ limit (1\% does not, $3 \%$ are undecided) and $72 \%$ adhere to the $10 \mathrm{~km} / \mathrm{h}$ limit $(15 \%$ do not, $13 \%$ are undecided). According to the residents, $57 \%$ of the population adhere to the parking regime by only parking in marked places in the neighbourhood (30\% do not, $13 \%$ are undecided). As the least likeable parts of the redesign, the residents have repeatedly stated that excessive speeds and illegal parking are still a problem and that it is necessary to introduce consistent speed control and more frequent traffic warden control.

The use was rated for parking spaces (residents and visitors), socializing and play areas (adults and children), pavement along the main street and segregated footpaths. Residents mostly use footpaths (96\%) and the pavement (95\%). Socializing and play areas are used by $70 \%$ of children and $50 \%$ of adults. Parking spaces are used by more than half of the population (54\%) and their visitors (55\%).

The impact of typical redesign elements on traffic calming was the category that received the lowest values. On average, only a little more than half of the population believes that redesigns have had an impact on traffic calming (59\%), 26\% do not, and $15 \%$ are undecided. According to the residents, the most effective element were speed humps ( $68 \%$ in favour and $22 \%$ against). This is followed by narrowing at the entry points to the neighbourhood ( $64 \%$ in favour and $27 \%$ against); narrowing of the carriageway with plantings, benches, playground equipment or parking spaces ( $62 \%$ in favour and $25 \%$ against) and the $30 \mathrm{~km} / \mathrm{h}$ speed limit on the main street (59\% in favour and $27 \%$ against). In the context of the impact on traffic calming, the pavement along the main street ( $53 \%$ in favour and $17 \%$ against) and building mini roundabouts ( $48 \%$ in favour and $36 \%$ against) were rated the lowest. The problematic nature of the latter was already detected in terms of acceptability and understandability.

The acceptability of the redesign of the neighbourhood into an area of comprehensively calmed traffic was also measured with questions about its most and least likeable part. Just under a quarter of the population likes the redesign in its entirety $(24 \%)$, while the other most frequently mentioned likeable elements are areas for socialising and playing $(14 \%)$, pavement for its safety $(12 \%)$, segregated footpaths $(10 \%)$ and side streets due to both calmed traffic and areas for socialising and playing $(10 \%)$. On the other hand, almost a third of the population likes mini roundabouts the least (29\%), followed by the narrowing of the carriageway $(8 \%)$, paving stones on the carriageway $(5 \%)$ and speed humps $(5 \%)$. These elements disturb the residents mainly because they hinder smooth driving. Among the criticisms were also the following more general comments: poor quality of construction works, poor 
maintenance of plantings and other arrangements, the need for consistent speed control to prevent speeding and for more frequent traffic warden control to prevent illegal parking.

\subsection{Vehicle Flows and Speeds}

Measurements of motorized traffic were carried out at four measuring locations in Juršovka residential neighbourhood in Ljutomer in Slovenia (Figure 4). Three measuring locations were on the main (transit) street through the neighbourhood: at 22 Kidričeva Street (location 1; micro-location after redesign: longer straight section, near the narrowing of the carriageway with parking spaces, an area with benches and a speed hump), 17 Jurčičeva Street (location 2; micro-location after redesign: longer straight section, between a speed hump and a narrowing of the carriageway with a parking space) and 1 Aškerčeva Street (location 3; entry point to the neighbourhood, micro-location after redesign: short straight section between two mini roundabouts). One measuring location was on a side (access) street at 11 Aškerčeva Street (location 4; micro-location after redesign: longer straight section near the narrowing of the carriageway with a parking space).

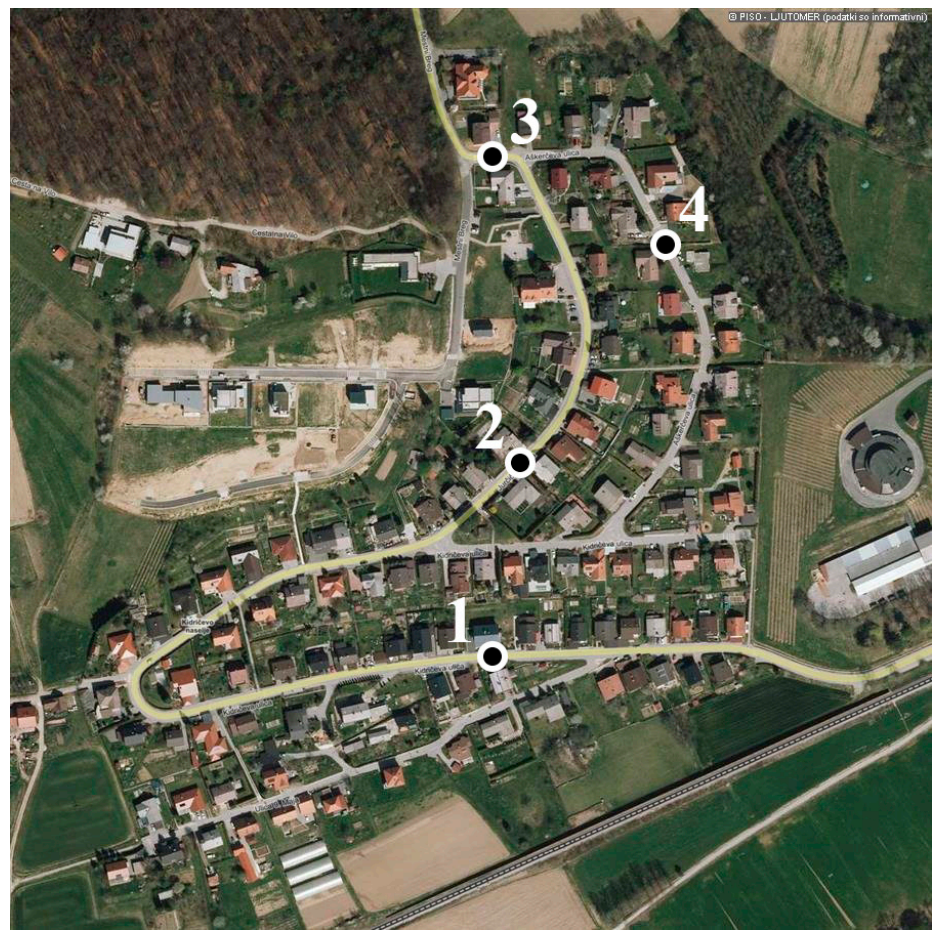

Figure 4. Juršovka residential neighbourhood in Ljutomer in Slovenia with marked measuring locations. Location 1: 22 Kidričeva Street, location 2: 17 Jurčičeva Street, location 3: 1 Aškerčeva Street and location 4: 11 Aškerčeva Street (source of background picture: www.geoprostor.net).

\subsubsection{Vehicle Flows and Classes before and after Redesign}

Data on the number of vehicles travelling towards the centre and away from the centre, for both directions together and on the peak hour flows for all four measuring locations and all three-time sections are shown in Table 4. The amount of traffic decreased throughout the neighbourhood after the redesign. The lowest number of vehicles was recorded in 2017, which may also be due to seasonal changes (measurements were carried out in July, when people already begin taking their leaves for summer holidays), but the quantities in 2018, when measurements were carried out in September, are only slightly higher than in 2017 and significantly lower than in 2014. As expected, the entry point to the neighbourhood is the busiest, and the access street is the least crowded. Vehicle flows proportionally decreased the most at the entry point and the least on the access street, which is not surprising since the latter is a characteristic route destination. 
Table 4. Vehicle flows and peak hour flows during measurements before (2014) and after (2017 and 2018) redesign showing the change for the period 2014-2018 for all four measuring locations.

\begin{tabular}{|c|c|c|c|c|c|}
\hline \multirow{2}{*}{$\begin{array}{l}\text { Measuring } \\
\text { Location }\end{array}$} & & \multicolumn{4}{|c|}{ Number of Vehicles in $24 \mathrm{~h}$} \\
\hline & & 17 June 2014 & 06 July 2017 & 26 September 2018 & Change 2014-2018 \\
\hline \multirow{4}{*}{$\begin{array}{c}\text { Location } 1 ; \\
\text { Kidričeva Street } \\
\text { (main street, } \\
\text { transit) }\end{array}$} & Direction toward centre & 163 & 110 & 118 & $-45(-28 \%)$ \\
\hline & Direction away from centre & 165 & 100 & 129 & $-36(-22 \%)$ \\
\hline & Both directions & 328 & 210 & 247 & $-81(-25 \%)$ \\
\hline & Peak hour flow & 39 & 19 & 28 & $-11(-11 \%)$ \\
\hline \multirow{4}{*}{$\begin{array}{c}\text { Location 2; } \\
\text { Jurčičeva Street } \\
\text { (main street, } \\
\text { transit) }\end{array}$} & Direction toward centre & 287 & 115 & 148 & $-139(-48 \%)$ \\
\hline & Direction away from centre & 277 & 124 & 169 & $-108(-39 \%)$ \\
\hline & Both directions & 564 & 239 & 317 & $-247(-44 \%)$ \\
\hline & Peak hour flow & 55 & 23 & 32 & $-23(-23 \%)$ \\
\hline \multirow{4}{*}{$\begin{array}{c}\text { Location } 3 ; \\
\text { Aškerčeva Street } \\
\text { (main street, transit, } \\
\text { entry point) }\end{array}$} & Direction toward centre & 444 & 282 & 291 & $-153(-34 \%)$ \\
\hline & Direction away from centre & 431 & 325 & 307 & $-124(-29 \%)$ \\
\hline & Both directions & 875 & 607 & 598 & $-277(-32 \%)$ \\
\hline & Peak hour flow & 95 & 65 & 67 & $-28(-29 \%)$ \\
\hline \multirow{4}{*}{$\begin{array}{c}\text { Location 4; } \\
\text { Aškerčeva Street } \\
\text { (side street, access) }\end{array}$} & Direction toward centre & 78 & 77 & 73 & $-5(-6 \%)$ \\
\hline & Direction away from centre & 75 & 65 & 77 & $2(+3 \%)$ \\
\hline & Both directions & 153 & 142 & 150 & $-3(-2 \%)$ \\
\hline & Peak hour flow & 18 & 14 & 17 & $-1(-6 \%)$ \\
\hline
\end{tabular}

From 2014 to 2018, the number of vehicles per working day on transit streets decreased by an average of $33 \%$. In 2018, there were 277 fewer vehicles recorded at the entry point to the neighbourhood ( $-32 \%$ compared to 2014$)$; on the two transit streets, there were 247 and 81 fewer vehicles $(-44 \%$ and $-25 \%$, respectively, compared to 2014), and on the access street, there were 3 fewer vehicles $(-2 \%$ compared to 2014). The average peak hour flow in the neighbourhood also decreased by just under a third $(-30 \%)$ from an average of 52 vehicles per hour in 2014 to an average of 36 in 2018. On transit streets, the average peak hour flow was reduced from 63 vehicles per hour in 2014 to 42 in $2018(-33 \%)$; the peak is between 15:00 and 16:00. On the access street, the peak hour flow remained practically the same (18 in 2014 and 17 in 2018) (-6\%), with the peak between 14:00 and 15:00.

The traffic counters used classify vehicles into 12 classes. At the time of the measurements, three different vehicle classes were recorded in the neighbourhood. The shares of each class are given below for the average of all measuring locations for each year of measurements. The majority of vehicles in the neighbourhood are passenger cars (vehicle class 2), namely, 99\% in 2014 and 2017 and 98\% in 2018. The remaining $1 \%$ and $2 \%$, respectively, are passenger cars with trailers and two-axle lorries or buses (vehicle classes 3 and 4); most of these vehicles were recorded on transit streets.

\subsubsection{Vehicle Speeds before and after Redesign}

Data on the proportions of passenger cars (vehicle class 2) according to the measured driving speed for all four measuring locations and all three-time sections are shown in Table 5. In general, the speed of passenger cars has significantly decreased throughout the neighbourhood after the redesign, although they have not yet reached the permitted speed limits, especially not on side streets with a speed limit of $10 \mathrm{~km} / \mathrm{h}$. The smallest changes in vehicle speeds were recorded at the entry point to the neighbourhood, where in all time sections most vehicles drove at speeds up to $30 \mathrm{~km} / \mathrm{h}$, probably due to the micro-location between two intersections or mini roundabouts (depending on the situation before and after redesign).

Only a small number of passenger cars drive less than $10 \mathrm{~km} / \mathrm{h}$ in the neighbourhood $(2 \%$ in 2014 and $1 \%$ in 2018), but the share of vehicles driving slower than $30 \mathrm{~km} / \mathrm{h}$ has increased on average by $20 \%$ (from $38 \%$ in 2014 to $58 \%$ in 2018), and the share of those who drive faster (30-50 km/h) decreased proportionally (from $59 \%$ in 2014 to $42 \%$ in 2018). Speeds above $50 \mathrm{~km} / \mathrm{h}$ are practically non-existent ( $3 \%$ in 2014 and $0.2 \%$ in 2018). The median speed on transit streets decreased on average by $6.0 \mathrm{~km} / \mathrm{h}$ and on the access street by $2.8 \mathrm{~km} / \mathrm{h}$. 
Table 5. Driving speeds of passenger cars during measurements before (2014) and after (2017 and 2018) redesign showing the change for the period 2014-2018 for all four measuring locations.

\begin{tabular}{|c|c|c|c|c|c|}
\hline \multirow{2}{*}{$\begin{array}{l}\text { Measuring } \\
\text { Location }\end{array}$} & & \multicolumn{4}{|c|}{ Share of Passenger Cars in Relation to Measured Driving Speed } \\
\hline & & Up to $10 \mathrm{~km} / \mathrm{h}$ & Up to $30 \mathrm{~km} / \mathrm{h}$ & $30-50 \mathrm{~km} / \mathrm{h}$ & Over $50 \mathrm{~km} / \mathrm{h}$ \\
\hline \multirow{4}{*}{$\begin{array}{l}\text { Location 1; } \\
\text { Kidričeva } \\
\text { Street (main } \\
\text { street, transit) }\end{array}$} & 17 June 2014 & $0 \%$ & $16 \%$ & $74 \%$ & $10 \%$ \\
\hline & 06 July 2017 & $1 \%$ & $41 \%$ & $55 \%$ & $3 \%$ \\
\hline & 26 September 2018 & $0 \%$ & $36 \%$ & $62 \%$ & $1 \%$ \\
\hline & Change 2014-2018 & $0 \%$ & $+20 \%$ & $-11 \%$ & $-9 \%$ \\
\hline \multirow{4}{*}{$\begin{array}{l}\text { Location 2; } \\
\text { Jurčičeva Street } \\
\text { (main street, } \\
\text { transit) }\end{array}$} & 17 June 2014 & $0 \%$ & $17 \%$ & $79 \%$ & $4 \%$ \\
\hline & 06 July 2017 & $0 \%$ & $70 \%$ & $29 \%$ & $0 \%$ \\
\hline & 26 September 2018 & $1 \%$ & $59 \%$ & $41 \%$ & $0 \%$ \\
\hline & Change 2014-2018 & $1 \%$ & $+42 \%$ & $-39 \%$ & $-4 \%$ \\
\hline \multirow{4}{*}{$\begin{array}{l}\text { Location 3; } \\
\text { Aškerčeva } \\
\text { Street (main } \\
\text { street, transit, }\end{array}$} & 17 June 2014 & $1 \%$ & $98 \%$ & $2 \%$ & $0 \%$ \\
\hline & 06 July 2017 & $1 \%$ & $85 \%$ & $11 \%$ & $4 \%$ \\
\hline & 26 September 2018 & $1 \%$ & $100 \%$ & $0 \%$ & $0 \%$ \\
\hline & Change 2014-2018 & $0 \%$ & $+2 \%$ & $-2 \%$ & $0 \%$ \\
\hline \multirow{4}{*}{$\begin{array}{l}\text { entry point) } \\
\text { Location 4; } \\
\text { Aškerčeva } \\
\text { Street (side } \\
\text { street, access) }\end{array}$} & 17 June 2014 & $2 \%$ & $32 \%$ & $67 \%$ & $1 \%$ \\
\hline & 06 July 2017 & $6 \%$ & $61 \%$ & $38 \%$ & $1 \%$ \\
\hline & 26 September 2018 & $1 \%$ & $50 \%$ & $50 \%$ & $0 \%$ \\
\hline & Change 2014-2018 & $-1 \%$ & $+18 \%$ & $-17 \%$ & $-1 \%$ \\
\hline
\end{tabular}

To show the change in passenger cars' speed through the neighbourhood, the most representative measuring location is 22 Kidričeva Street (Figure 5), which is located on a long straight section without major intersections and after redesign is close to two typical elements (narrowing of the carriageway by parking spaces and bench areas along the carriageway and a speed hump). Prior to the redesign, most passenger cars drove through the neighbourhood at speeds between 30 and $50 \mathrm{~km} / \mathrm{h}\left(\mathrm{V}_{85}\right.$ in 2014 was $48.25 \mathrm{~km} / \mathrm{h}$ ), and after the redesign, most drove at speeds between 20 and $40 \mathrm{~km} / \mathrm{h}\left(\mathrm{V}_{85}\right.$ in 2018 was $41.28 \mathrm{~km} / \mathrm{h}$ ). A comparison of the cumulative shares of passenger cars for individual driving speeds for the period before (2014) and after (2017 and 2018) redesign for all four measuring locations is shown in Figure 6.

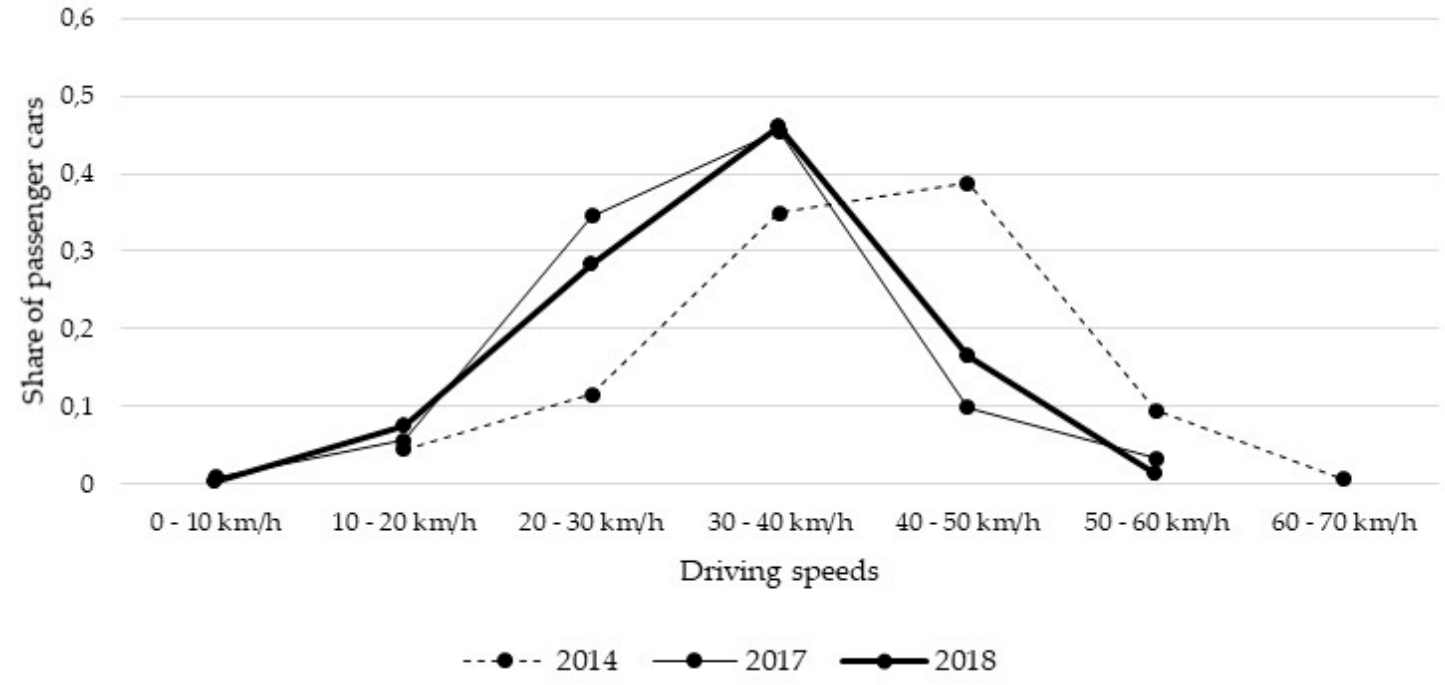

Figure 5. Driving speeds of passenger cars at the 22 Kidričeva Street measuring location during the measurements before (2014) and after (2017 and 2018) redesign. 


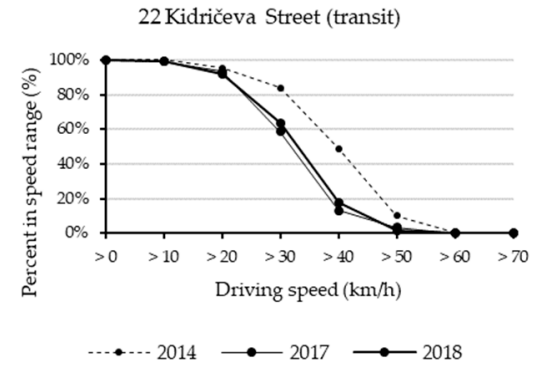

(a)

1 Aškerčeva Street (transit, entry point)

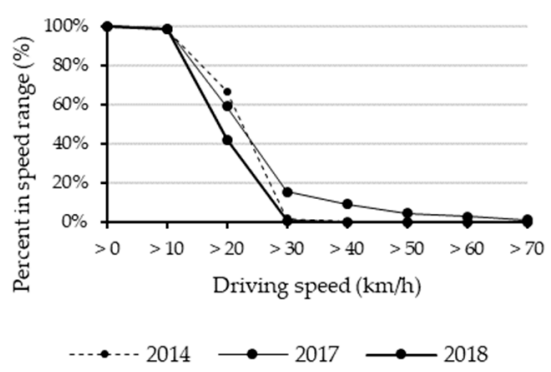

(c)

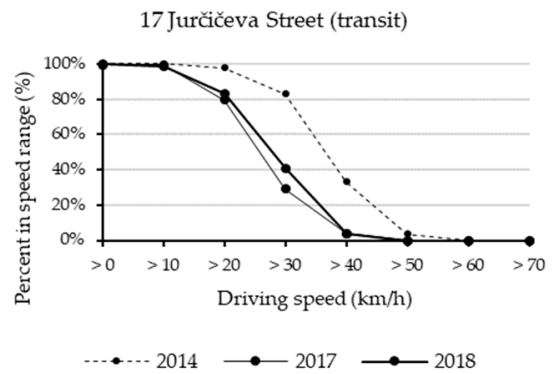

(b)

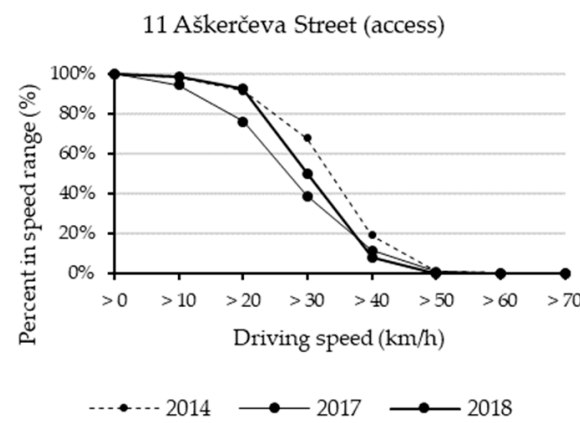

(d)

Figure 6. Comparison of cumulative shares of passenger cars for individual driving speeds for the period before (2014) and after (2017 and 2018) redesign for all four measuring locations; (a) location 1: 22 Kidričeva Street, (b) location 2: 17 Jurčičeva Street, (c) location 3: 1 Aškerčeva Street and (d) location 4: 11 Aškerčeva Street.

There are few larger vehicles of vehicle classes 3 and 4 in the neighbourhood (1.1\% (23) in 2014, $0.8 \%$ (9) in 2017 and 1.5\% (20) in 2018). A comparison of 2014 and 2018, with practically the same number of larger vehicles, showed a reduction in driving speed in the neighbourhood. In $2018,75 \%$ of larger vehicles drove slower than $30 \mathrm{~km} / \mathrm{h}$ (52\% in 2014). No larger vehicle drove faster than $50 \mathrm{~km} / \mathrm{h}$ either before or after the redesign.

\subsection{Traffic Safety}

In the period 2000-2019, there were 802 traffic accidents with 1310 participants in the settlement of Ljutomer, 17 participants had serious injuries (including one pedestrian and four cyclists); there were no fatalities. Regarding traffic accidents, the Juršovka neighbourhood is not a problematic area. In the same period, there were only 12 traffic accidents (1.5\% of the settlement total) with 21 participants (1.6\% of the settlement total), all of which were without serious injuries or death, and only one participant had minor injuries. A comparison of data for the settlement of Ljutomer and the Juršovka neighbourhood before and after the redesign is given in Table 6 below.

No pedestrians or cyclists were involved in the accidents in the neighbourhood. The most common causes were unadjusted speed ( $25 \%$ ) and incorrect side or direction of travel $(25 \%)$, which in most cases resulted in a collision into an object $(45 \%)$ or a collision of vehicles $(27 \%)$. The majority of accidents (11, or $92 \%$ ) occurred on transit streets (6 on Kidričeva Street, 4 on Mestni breg next to the entry point to the neighbourhood at Aškerčeva street, and one on Jurčičeva Street). One accident occurred on the access street (Aškerčeva Street). Most accidents in the neighbourhood occurred before the redevelopment (11, or 92\%, between 2000 and 2010), and after the redevelopment only one (in 2018 on Kidričeva Street, a vehicle collided with a building due to the wrong side or direction of travel). 
Table 6. Traffic accidents in the settlement of Ljutomer and the Juršovka neighbourhood in the period before (2000-2016) and after (2016-2019) redesign.

\begin{tabular}{ccccc}
\hline \multirow{2}{*}{ Period and Monitored Categories } & \multicolumn{2}{c}{ Traffic Accidents-Locations, Number and Shares of } \\
Monitored Categories
\end{tabular}

\section{Discussion}

Almost thirty years after the concept of sustainable mobility appeared on the international agenda, we are still far away from achieving a sustainable mobility system [7], and predominantly dependent on private car for mobility [10,54]. To avert this trend, we must focus on people and plan for them $[1,55]$. Several authors agree that neighbourhoods are among the most important places to do that $[1,23,56]$. The redesign of the Juršovka neighbourhood in Ljutomer is a step in this direction.

Comprehensive traffic calming measures were used for the neighbourhood redesign, following the principles of sustainable mobility paradigm [1] and SUM planning. The results of monitoring and rating by the residents show positive effects towards achieving the key objectives, namely, improving accessibility, quality of life and traffic safety, and increasing the use of sustainable travel modes [1-4]. Positive effects for a similar broader set of indicators are also reported in a study from the United Kingdom [57], which monitored and evaluated nine pilot areas for the conversion of residential neighbourhoods into calm residential zones (so-called Home zones), and in a report from Vitoria-Gasteiz in Spain [58], which examined the setup of a pilot traffic-friendly area (so-called Superblock). These two documents are a rare example of monitoring and evaluating a wider range of comprehensive traffic calming effects as opposed to a large number of studies focusing on traffic safety and vehicle flows and speeds reduction [23,59-65].

All three studies report an increase in the use of active mobility and an improvement of the quality of living environment. In Ljutomer, after the redesign, a little over a third of the population (37\%) walk more often, and just under a third (27\%) cycle more often. Youth under the age of 18 have changed their habits the most, followed by adults and the elderly. Just under two thirds of the population (63\%) believe that the quality of living in the neighbourhood has improved significantly. Most of them show strong support for the redesign elements $(75 \%)$, and just under a quarter like the redesign in its entirety $(24 \%)$. The higher quality of the living environment is also confirmed by the fact that after the redesign $28 \%$ of the population spends more time outside and socialising with neighbours, and that $70 \%$ of children and $50 \%$ of adults use community and play areas. According to residents, the key elements of the redesign that contributed most to the above effects are the pavement along the main street through the neighbourhood; renovation of segregated footpaths; plantings with trees, shrubs and perennials and the $30 \mathrm{~km} / \mathrm{h}$ speed limit on the main street. Residents agree the least with the mini roundabouts and traffic calming by narrowing at both entry points to the neighbourhood. 
The study from United Kingdom [57] states that $10 \%$ of the population reported more frequent cycling, $44 \%$ thought that walking after the redesign was more pleasant while $12 \%$ spent more time outside. Of the population, $64 \%$ supported the redesign, $73 \%$ of them thought that their living environment was now more attractive. By far the most desirable element proved to be plantings with trees, shrubs and perennials. The pilot redesign in Vitoria-Gasteiz [58] received a score of 7.4 on a ten-point scale of acceptance among the population, and the redesign greatly affected the change in travel habits. The elimination of transit traffic from the area helped to reduce motorized traffic to less than $20 \%$, while the number of pedestrians increased by $57 \%$ and the number of cyclists by $9 \%$.

Residents rated highly the elements of the redevelopment, such as trees, exclusive routes for walking and cycling, quality public spaces, urban equipment, and public green spaces. These elements are an important added value that comprehensive traffic calming adds to the more technical elements of traffic calming. The results support paradigms of creating streets as spaces for people and not for cars $[1,31,55,66]$, and the same elements are recognized in the literature as important factors in providing a supportive environment for the more frequent use of active mobility and increasing health benefits [20]. Synergies with other modern paradigms of establishing green, healthy cities that are pleasant to live in $[24,25]$ also show the potential of linking sustainable urban mobility planning with the planning of public green spaces.

Redesigns of the studied areas also had a positive effect on reducing vehicle flows and speeds. In Ljutomer, the number of vehicles per working day decreased on transit streets on average by $33 \%$ and on the access street by $2 \%$. The average peak hour flow decreased by almost a third $(-30 \%)$ as well. Driving speeds have also decreased, although the target speeds of $30 \mathrm{~km} / \mathrm{h}$ on transit and $10 \mathrm{~km} / \mathrm{h}$ on access streets have not (yet) been reached. The $\mathrm{V}_{85}$ at the representative measuring location decreased by $6.97 \mathrm{~km} / \mathrm{h}$ to $41.3 \mathrm{~km} / \mathrm{h}$. The median speed on transit streets decreased on average by $6.0 \mathrm{~km} / \mathrm{h}$, and on the access street by $2.8 \mathrm{~km} / \mathrm{h}$. The share of vehicles driving slower than $30 \mathrm{~km} / \mathrm{h}$ increased on average by $20 \%$ (to $58 \%$ ), while the share of those driving between 30 and $50 \mathrm{~km} / \mathrm{h}$ decreased proportionally (from $59 \%$ to $42 \%$ ). The speed practically does not reach above $50 \mathrm{~km} / \mathrm{h}(0.2 \%)$, but almost no one drives below $10 \mathrm{~km} / \mathrm{h}(1 \%)$ either. The residents still perceive speeds as fairly high, as only a little over a half of them believe that the redesign has had an impact on traffic calming. Perception may be based on rare speeding vehicles, which residents tend to remember more than the majority of vehicles driving slowly [57]. On the other hand, the residents are not self-critical enough, with $96 \%$ claiming to comply with the $30 \mathrm{~km} / \mathrm{h}$ limit and $72 \%$ claiming to comply with the $10 \mathrm{~km} / \mathrm{h}$ limit.

The aforementioned study from the United Kingdom [57] measured a smaller reduction in the volume of traffic on transit streets (by $25 \%$ ), while traffic calming was more effective. The $\mathrm{V}_{85}$ decreased on average by $9.7 \mathrm{~km} / \mathrm{h}$ to less than $30 \mathrm{~km} / \mathrm{h}$, and the median speed decreased on average by $8.0 \mathrm{~km} / \mathrm{h}$, but the starting speeds were lower $(58 \%$ of vehicles drove slower than $30 \mathrm{~km} / \mathrm{h}$ before the redesign and $88 \%$ after). Interestingly, only $20 \%$ of the population there reported driving slower after the redesign. The average speed of motorized traffic in Vitoria-Gasteiz [58] decreased by $2.2 \mathrm{~km} / \mathrm{h}$, but the speeds there were already lower as well before the redesign (below $30 \mathrm{~km} / \mathrm{h}$ ). Other studies report speed drops ranging from up to $6 \mathrm{~km} / \mathrm{h}$ in Denmark [67] to up to $11 \mathrm{~km} / \mathrm{h}$ in the United States and up to $18 \mathrm{~km} / \mathrm{h}$ in the United Kingdom [60].

It is likely that the reduction of driving speeds in the neighbourhood results from both the reduction in vehicle flows (i.e., residents driving slower than vehicles in transit) as well as the effect of redesign elements. Measuring locations were located nearby different redesign elements with consequently different effects on reducing driving speeds. Location 2 (17 Jurčičeva Street) showed to be most successful in speed reduction. There, share of vehicles driving slower than $30 \mathrm{~km} / \mathrm{h}$ increased by $53 \%$ in short-term and by $42 \%$ in mid-term. This measuring location was directly between two redesign elements (a speed hump and a narrowing of the carriageway with a parking space). We suppose this is the reason for more rigorous reduction in driving speeds since other two locations on similar sections of streets (location 1 at 22 Kidričeva Street and location 4 at 11 Aškerčeva Street) were located on one side of one or a combination of several redesign elements. There, smaller speed reductions 
were measured (share of vehicles driving slower than $30 \mathrm{~km} / \mathrm{h}$ increased by $25 \%$ and $29 \%$ in short-term and $20 \%$ and $18 \%$ in mid-term, respectively). While very few vehicles drove faster than $30 \mathrm{~km} / \mathrm{h}$ before the redesign at location 3 ( 1 Aškerčeva Street), this is the only location where all passenger cars $(100 \%)$ drove slower than the target speed of $30 \mathrm{~km} / \mathrm{h}$ in mid-term ( $85 \%$ in short-term). Its micro-location after the redesign is between two redesign elements (in this case two mini roundabouts). Interestingly, the latter present the most negatively accepted and least understood redesign element according to residents' responses. Therefore, it is likely that in the short-term some residents were driving directly over the mini roundabouts and consequently reached a higher speed at the measuring location while in the mid-term they started to use the mini roundabouts correctly followed by slower driving in-between them. All locations show trend inversion in speed reduction when comparing short- and mid-term measurements. It is most likely that this occurred due to residents getting familiar with the redesign elements. It would be interesting to measure driving speeds and implement a survey on the perception of the redesign elements to gather information and data on long-term effects of the redesign.

The last indicator is traffic safety. From the point of view of traffic accidents, the Juršovka neighbourhood in Ljutomer is not a problematic area, but the fact that $92 \%$ of accidents occurred before the redesign still speaks in favour of the redesign. Between 2000 and 2019, there were 12 traffic accidents in the neighbourhood (1.5\% of the settlement total). All were without serious injury or death, and no pedestrians or cyclists were involved. After the redesign, only one accident occurred (in 2018 on a transit street, a vehicle collided into a building). Traffic accidents were not a problem in the pilot areas in United Kingdom either (in all areas there were 19 in the five years before and 1 after the redesign) [57], while in Vitoria-Gasteiz they were not monitored.

Despite the optimistic results from the studied areas, positive traffic calming effects on traffic safety reported from several other studies $[23,60]$ and the improvement of traffic safety in Europe and Slovenia in general in recent years, the fact that settlements are still the most dangerous traffic areas is worrying. In 2017, 63\% of all accidents and 35\% of all fatal accidents in Slovenia occurred in settlements [68]. At European Union level, too, almost half of fatal traffic accidents occur in cities [69]. This indicates the need to change the approach to ensuring road safety. In recent years, a new paradigm has been introduced $[18,33]$. With it, the focus on motorized traffic, traffic safety and the reduction in driving speed typical of the classical paradigm has shifted to reducing the number of vehicles. New research shows that any use of motor vehicle poses a risk and that there are more fatal traffic accidents in environments with a higher number of kilometres driven [18,33]. Strategies to reduce car use and promote the use of alternative travel modes, such as sustainable urban mobility planning, thus reduce the risk of accidents and consequently increase road safety [62,70,71].

The effects of the redesign of the Juršovka neighbourhood in Ljutomer in line with the principles of comprehensive traffic calming and sustainable mobility paradigm [1] confirm the positive results of similar previous studies from the United Kingdom (2005) and Spain (2013) as well as from broader research on positive effects of traffic calming and measures improving conditions for sustainable mobility $[1,23,40,56,58,72]$. They prove that the effectiveness of such redesigns has not decreased over time. All the results show more active travel habits, higher quality of living, greater traffic safety, less motorized traffic and lower driving speeds, so it is unusual that the approach has not yet become a common design practice [60]. The planning process itself, which was highly transparent and inclusive and followed the key steps in the preparation of the SUMP, certainly contributed to the success of the measure [39]. The latter furthermore encouraged the Municipality of Ljutomer to define other areas of comprehensively calmed traffic in the municipality and to already order the production of detailed plans for four areas.

The development of a common methodology for monitoring the effects of comprehensive traffic calming would certainly be a welcome help and encouragement to other local communities, which would expand the knowledge base in this field by monitoring the effects of similar redesigns. An important factor for the wider use of comprehensive traffic calming is its placement and promotion within sustainable urban mobility planning and as a basic planning unit of SUMPs as was already 
promoted by the author and her colleagues from the Urban Planning Institute of the Republic of Slovenia [46]. Taking into account the already expressed need for coordinated packages of mutually reinforcing transport and land-use policies [2] and successful examples from Western Europe [56], it would also be necessary to explore the potential for its placement in traffic and spatial planning practice in Slovenia and other countries where traditional planning approaches still prevail.

\section{Conclusions}

Negative impacts of motor vehicle traffic in cities are still increasing despite the objectives that sustainable mobility paradigm put forward almost three decades ago. Measures to reduce them still primarily focus on traffic safety improvements through vehicle flows and speeds reduction (traffic calming). Comprehensive traffic calming targets the issue more comprehensively by also addressing changes in travel behaviour and quality of life and thus pursues objectives of sustainable mobility paradigm. Literature covering the effects of measures addressing all listed aspects is scarce.

Results of a longitudinal study presented in this paper show how the comprehensive traffic calming redesign of a residential neighbourhood impacts walking and cycling habits, quality of life, motorized traffic and road safety in a positive way. The studied redesign took place in 2016 while ex ante data gathering took place in 2014 and ex post data gathering took place in 2017 and 2018. Surveys and pilot interviews were used to consult residents; automatic pneumatic traffic counters were used to collect data on motorized traffic, and public databases were used to gather data on traffic accidents.

Around a third of residents claim to walk $(37 \%)$, cycle $(27 \%)$ and socialize $(28 \%)$ more than before while around two thirds (63\%) state that the quality of life in the neighbourhood has improved, and $75 \%$ strongly support the redesign elements. Moreover, vehicle speeds and flows and peak-hour flows have notably decreased throughout the neighbourhood. On average, the share of vehicles driving at less than $30 \mathrm{~km} / \mathrm{h}$ increased by $20 \%$ (from $38 \%$ to $58 \%$ ), mostly due to a reduction in the number driving between 30 and $50 \mathrm{~km} / \mathrm{h}$ ( $59 \%$ before, $42 \%$ after). The share of vehicles exceeding $50 \mathrm{~km} / \mathrm{h}$ has dropped to almost zero ( $3 \%$ before, $0.2 \%$ after). The 85 th percentile speeds at a representative location were reduced by $6.97 \mathrm{~km} / \mathrm{h}$ to $41.3 \mathrm{~km} / \mathrm{h}$. The average traffic flows on transit streets have decreased by $33 \%$ and on the access street by $2 \%$. The average maximum peak hour flows have decreased by $30 \%$ (from 52 to 36 vehicles in the peak hour). Compared to the whole settlement of Ljutomer, very few traffic accidents occurred in the neighbourhood and only one after the redesign. All accidents were without casualties or serious injuries, and no pedestrians or cyclists were involved.

The results show a broad range of positive impacts of the comprehensive traffic calming approach and are confirmed by similar studies from the United Kingdom, Spain and elsewhere. Its potential for wider use in planning practice is substantial and should be promoted within the context of sustainable urban mobility planning and as a basic planning unit in SUMPs as is already the case in Slovenia. Furthermore, the development of a uniform approach to monitoring the effects of comprehensive traffic calming measures could also help to support and encourage other local authorities to monitor similar measures.

Author Contributions: Conceptualization, M.B. and M.L.; methodology, M.B.; investigation, M.B.; data curation, M.B.; writing — original draft preparation, M.B.; writing—review and editing, M.L.; visualization, M.B.; supervision, M.L. All authors have read and agreed to the published version of the manuscript.

Funding: This research received no external funding.

Conflicts of Interest: The authors declare no conflict of interest.

\section{References}

1. Banister, D. The sustainable mobility paradigm. Transp. Policy 2008, 15, 73-80. [CrossRef]

2. Marshall, S. The challenge of sustainable transport. In Planning for a Sustainable Future; Layard, A., Davoudi, S., Batty, S., Eds.; Spon Press: London, UK, 2001; pp. 131-147. ISBN 978-0-415-23227-2. 
3. European Commission (EC). Together towards Competitive and Resource-Efficient Urban Mobility, COM 913 Final. Available online: https://ec.europa.eu/transport/themes/urban/urban_mobility/ump_en (accessed on 22 June 2018).

4. European Commission (EC). Action Plan on Urban Mobility, COM 490 Final. Available online: http: //ec.europa.eu/transport/themes/urban/urban_mobility/action_plan_en.htm (accessed on 22 June 2018).

5. Rupprecht, S.; Brand, L.; Böhler-Baedeker, S.; Brunner, L.M. Guidelines for Developing and Implementing a Sustainable Urban Mobility Plan, 2nd ed.; Rupprecht Consult: Köln, Germany, 2019.

6. Plevnik, A.; Mladenovič, L.; Balant, M.; Koblar, S. Nacionalni Program Celostnega Prometnega Načrtovanja 2018-2028; Ministrstvo RS za infrastrukturo: Ljubljana, Slovenia, 2018.

7. Holden, E.; Gilpin, G.; Banister, D. Sustainable Mobility at Thirty. Sustainability 2019, 11, 1965. [CrossRef]

8. Freudendal-Pedersen, M.; Kesselring, S.; Servou, E. What is Smart for the Future City? Mobilities and Automation. Sustainability 2019, 11, 221. [CrossRef]

9. Næss, P.; Vogel, N. Sustainable urban development and the multi-level transition perspective. Environ. Innov. Soc. Transit. 2012, 4, 36-50. [CrossRef]

10. Freudendal-Pedersen, M. Mobility in daily life: Between freedom and unfreedom. In Transport and Society; Ashgate: Surrey, UK, 2009; ISBN 978-0-7546-7490-0.

11. European Commission (EC). White Paper. Roadmap to a Single European Transport Area-Towards a Competitive and Resource Efficient Transport System, COM 144 Final. Available online: http://ec.europa.eu/ transport/themes/strategies/2011_white_paper_en.htm (accessed on 22 June 2018).

12. European Commission (EC). A European Strategy for Low-Emission Mobility, COM 501 Final. Available online: https://ec.europa.eu/transport/sites/transport/files/themes/strategies/news/doc/2016-07-20decarbonisation/com\%282016\%29501_en.pdf (accessed on 22 June 2018).

13. European Transport Safety Council (ETSC). Available online: www.etsc.eu (accessed on 1 May 2020).

14. Plevnik, A. Okolje, Promet in Zdravje; Agencija RS za okolje: Ljubljana, Slovenia, 2016.

15. Welle, B.; Wei, L.; Adriazola, C.; King, R.; Obelheiro, M.; Sarmiento, C.; Liu, Q. Cities Safer by Design: Guidance and Examples to Promote Traffic Safety Through Urban and Street Design: Version 1.0; World Resource Institute: Washington, DC, USA, 2015; ISBN 978-1-56973-866-5.

16. World Health Organisation (WHO). Physical Activity, Key Facts. Available online: www.who.int/news-room/ fact-sheets/detail/physical-activity (accessed on 4 April 2020).

17. World Health Organisation (WHO). Available online: www.who.int (accessed on 1 May 2020).

18. Litman, T. A New Traffic Safety Paradigm; Victoria Transport Policy Institute: Victoria, BV, Canada, 2020 ; p. 45.

19. Plevnik, A.; Balant, M.; Mladenovič, L. Skrb vzbujajoče spremembe v mobilnosti mladih-primer osnovnošolcev v Novem mestu. Urbani Izziv 2017, 28, 70-79. [CrossRef]

20. De Nazelle, A.; Nieuwenhuijsen, M.J.; Antó, J.M.; Brauer, M.; Briggs, D.; Braun-Fahrlander, C.; Cavill, N.; Cooper, A.R.; Desqueyroux, H.; Fruin, S.; et al. Improving health through policies that promote active travel: A review of evidence to support integrated health impact assessment. Environ. Int. 2011, 37, 766-777. [CrossRef]

21. Mueller, N.; Rojas-Rueda, D.; Cole-Hunter, T.; de Nazelle, A.; Dons, E.; Gerike, R.; Götschi, T.; Int Panis, L.; Kahlmeier, S.; Nieuwenhuijsen, M. Health impact assessment of active transportation: A systematic review. Prev. Med. 2015, 76, 103-114. [CrossRef]

22. Kelly, P.; Kahlmeier, S.; Götschi, T.; Orsini, N.; Richards, J.; Roberts, N.; Scarborough, P.; Foster, C. Systematic review and meta-analysis of reduction in all-cause mortality from walking and cycling and shape of dose response relationship. Int. J. Behav. Nutr. Phys. Act. 2014, 11, 132. [CrossRef]

23. Pucher, J.; Buehler, R. Making Cycling Irresistible: Lessons from The Netherlands, Denmark and Germany. Transp. Rev. 2008, 28, 495-528. [CrossRef]

24. Leeuw, E.; De Tsouros, A.D.; Dyakova, M.; Green, G. Healthy Cities, Promoting Health and Equity-Evidence for Local Policy and Practice: Summary Evaluation of Phase V of the WHO European Healthy Cities Network; World Health Organisation Regional Office for Europe: Copenhagen, Denmark, 2014; ISBN 978-92-890-5069-2.

25. State of Green. Sustainable Urban Transportation. Creating Green Liveable Cities; Version 1.0.; State of Green: Çopenhagen, Denmark, 2016.

26. European Commission (EC). Urban Agenda for the EU. Partnership for Urban Mobility. Developing Guidelines on Infrastructure for Active Mobility Supported by Relevant Funding. Available online: https:/ec.europa.eu/ futurium/en/system/files/ged/final_deliverable_action_5.pdf (accessed on 22 September 2020). 
27. Carmona, M.; Heath, T.; Oc, T.; Tiesdell, S. Public Places-Urban Spaces: The Dimensions of Urban Design, 2nd ed.; Carmona, M., Ed.; Architectural Press: Oxford, UK; Elsevier: Amsterdam, The Netherlands, 2010; ISBN 978-1-85617-827-3.

28. Carmona, M.; Gabrieli, T.; Hickman, R.; Laopoulou, T.; Livingstone, N. Street appeal: The value of street improvements. Prog. Plan. 2018, 126, 1-51. [CrossRef]

29. Gehl, J. Cities for People; Island Press: Washington, DC, USA, 2010; ISBN 978-1-59726-573-7.

30. Gehl, J. Life between Buildings: Using Public Space; Island Press: Washington, DC, USA, 2011; ISBN 978-1-59726-827-1.

31. Jones, P.; Marshall, S.; Boujenko, N. Creating More People-Friendly Urban Streets Through 'Link and Place' Street Planning and Design. IATSS Res. 2008, 32, 14-25. [CrossRef]

32. Lauwers, D. Functional road categorization: New concepts and challenges related to traffic safety, traffic management and urban design-reflections based on practices in Belgium confronted with some Eastern European cases. In Proceedings of the Transportation and Land Use Interaction, Bucharest, Hungary, 23-25 October 2008; Volume 8, pp. 149-164.

33. Litman, T. Evaluating Transportation Diversity: Multimodal Planning for Efficient and Equitable Communities; Victoria Transport Policy Institute: Victoria, BC, Canada, 2017; p. 41.

34. University of Leeds KonSULT. The Knowledgebase on Sustainable Urban Land Use and Transport. Available online: http://www.konsult.leeds.ac.uk/ (accessed on 31 July 2017).

35. Vivanco, A.A.; Escudero, J.C. The Sustainable Urban Mobility Plan of Vitoria Gasteiz, Spain, CIVITAS PROSPERITY Project. 2017.

36. Escudero, J.C. Innovation brief on Superblocks, CIVITAS PROSPERITY Project. 2017.

37. Goeminne, J.; Hanssens, C. The Sustainable Urban Mobility Plan of Sint Niklaas, Belgium, CIVITAS PROSPERITY Project. 2017.

38. Ajuntament de Barcelona. Let's fill streets with life: Establishing Superblocks in Barcelona. Ajuntament de Barcelona, Commission for Ecology, Urban Planning and Mobility. 2016.

39. ISIS. Civitas Modern. Final Evaluation Report, CIVITAS MODERN Project. 2013.

40. De Geest, L. Gent's Traffic Circulation Plan. ELTIS. Available online: www.eltis.org/discover/case-studies/ gents-traffic-circulation-plan-belgium (accessed on 11 August 2020).

41. Ministrstvo RS za infrastrukturo (MZI). Infrastruktura za pešce. Splošne usmeritve. Verzija 1.0; Ministrstvo RS za Infrastrukturo: Ljubljana, Slovenia, 2017.

42. Bartle, C.; Calvert, T.; Clark, B.; Hüging, H.; Jain, J.; Melia, S.; Mingardo, G.; Rudolph, F.; Ricci, M.; Parkin, J.; et al. The Economic Benefits of Sustainable Urban Mobility Measures. Independent Review of Evidence: Reviews; EVIDENCE Project: Brussels, Belgium, 2016.

43. Shergold, I.; Parkhurst, G. The Economic Benefits of Sustainable Urban Mobility Measures. Independent Review of Evidence: Method; EVIDENCE Project: Brussels, Belgium, 2016.

44. Brown, V.; Moodie, M.; Carter, R. Evidence for associations between traffic calming and safety and active transport or obesity: A scoping review. J. Transp. Health 2017, 7, 23-37. [CrossRef]

45. Plevnik, A.; Mladenovič, L.; Balant, M.; Ružić, L. Prijazna mobilnost za zadovoljno prihodnost: Prometna strategija Občine Ljutomer; Ministrstvo RS za infrastrukturo in prostor: Ljubljana, Slovenia, 2012.

46. Balant, M.; Plevnik, A. People friendly travel zones as a basic planning unit in SUMPs—Case study from Ljutomer. In Proceedings of the 6th International Conference "Towards a Humane City", Novi Sad, Serbia, 26-27 October 2017; pp. 149-164.

47. Sheller, M.; Urry, J. The New Mobilities Paradigm. Environ. Plan. A 2006, 38, 207-226. [CrossRef]

48. Ščetinin, V.; Balant, M.; Plevnik, A.; Mladenovič, L. Ureditev Stanovanjske Soseske Juršovka kot Območja Prijaznega Prometa, Projektna Dokumentacija IDP; Biro skiro: Ljubljana, Slovenia, 2014.

49. CIVITAS PROSPERITY Project. Available online: http://sump-network.eu/ (accessed on 7 August 2020).

50. Lep, M.; Turnšek, S.; Vodnik, S. Prometna študija: Izvedba štetja prometa, meritev hitrosti in analiza rezultatov $v$ Občini Ljutomer; Fakulteta za gradbeništvo, Univerza v Mariboru: Maribor, Slovenia, 2014.

51. Lep, M.; Turnšek, S. Prometna študija: Izvedba štetja prometa, meritev hitrosti in analiza rezultatov v Občini Ljutomer; Fakulteta za gradbeništvo, prometon inženirstvo in arhitekturo, Univerza v Mariboru: Maribor, Slovenia, 2017. 
52. Lep, M.; Turnšek, S. Prometna študija: Izvedba štetja prometa, meritev hitrosti in analiza rezultatov v Občini Ljutomer; Fakulteta za gradbeništvo, prometno inženirstvo in arhitekturo, Univerza v Mariboru: Maribor, Slovenia, 2018.

53. Ministrstvo RS za Notranje Zadeve (MNZ): Prometna Varnost, Statistične Datoteke. Available online: https://www.policija.si/o-slovenski-policiji/statistika/prometna-varnost (accessed on 24 July 2020).

54. Urry, J. The 'System' of Automobility. Theory Cult. Soc. 2004, 21, 25-39. [CrossRef]

55. Appleyard, D. Livable Streets; University of California Press: Berkeley, CA, USA, 1981; ISBN 978-0-520-03689-5.

56. Buehler, R.; Pucher, J.; Gerike, R.; Götschi, T. Reducing car dependence in the heart of Europe: Lessons from Germany, Austria, and Switzerland. Transp. Rev. 2017, 37, 4-28. [CrossRef]

57. Webster, D.; Tilly, A.; Wheeler, A.; Nicholls, D.; Buttress, S. Pilot home zone schemes: Summary of the schemes, prepared for Traffic Management Division, Department for Transport; Webster, D., Ed.; TRL report; TRL Limited: Crowthorne, UK, 2005; ISBN 978-1-84608-653-3.

58. CIVITAS POINTER. Superblocks Model. Vitoria-Gasteiz, CIVITAS POINTER Project, CIVITAS POINTER Project. 2013.

59. Vaitkus, A.; Čygas, D.; Jasiūnienè, V.; Jateikienè, L.; Andriejauskas, T.; Skrodenis, D.; Ratkevičiūtè, K. Traffic Calming Measures: An Evaluation of the Effect on Driving Speed. PROMET 2017, 29, 275-285. [CrossRef]

60. Ewing, R.; Dumbaugh, E. The Built Environment and Traffic Safety: A Review of Empirical Evidence. J. Plan. Lit. 2009, 23, 347-367. [CrossRef]

61. Elvik, R. Transportøkonomisk institutt (Norway). In The Power Model of the Relationship between Speed and Road Safety: Update and New Analyses; Transportøkonomisk Institutt: Oslo, Norway, 2009; ISBN 978-82-480-1002-9.

62. Elvik, R.; Bjørnskau, T. Safety-in-numbers: A systematic review and meta-analysis of evidence. Saf. Sci. 2017, 92, 274-282. [CrossRef]

63. Richter, E.D.; Berman, T.; Friedman, L.; Ben-David, G. Speed, road injury, and public health. Annu. Rev. Public Health 2006, 27, 125-152. [CrossRef]

64. Bunn, F.; Collier, T.; Frost, C.; Ker, K.; Steinbach, R.; Roberts, I.; Wentz, R. Area-wide traffic calming for preventing traffic related injuries. Cochrane Database Syst. Rev. 2003. [CrossRef]

65. Elvik, R. Area-wide urban traffic calming schemes: A meta-analysis of safety effects. Accid. Anal. Prev. 2001, 33, 327-336. [CrossRef]

66. Jones, P.; Boujenko, N. Link and Place: A New Approach to Street Planning and Design. Road Transp. Res. 2009, 18, 38-48.

67. Agerholm, N.; Knudsen, D.; Variyeswaran, K. Speed-calming measures and their effect on driving speed-Test of a new technique measuring speeds based on GNSS data. Transp. Res. Part. F: Traffic Psychol. Behav. 2017, 46, 263-270. [CrossRef]

68. Javna agencija RS za varnost prometa (AVP). Analiza in Pregled Stanja Varnosti v Cestnem Prometu za leto 2017; Javna Agencija RS za varnost prometa: Ljubljana, Slovenia, 2018; p. 13.

69. European Commission (EC). On the Implementation of Objective 6 of the European Commission's Policy Orientations on Road Safety 2011-2020-First Milestone Towards an Injury Strategy, SWD 94 final. 2013. Available online: https://ec.europa.eu/transport/road_safety/sites/roadsafety/files/pdf/ser_inj/ser_inj_swd.pdf (accessed on 22 June 2018).

70. Jacobsen, P.L. Safety in numbers: More walkers and bicyclists, safer walking and bicycling. Inj. Prev. 2003, 9, 205-209. [CrossRef] [PubMed]

71. Fyhri, A.; Sundfør, H.B.; Bjørnskau, T.; Laureshyn, A. Safety in numbers for cyclists-conclusions from a multidisciplinary study of seasonal change in interplay and conflicts. Accid. Anal. Prev. 2016, 105, 124-133. [CrossRef] [PubMed]

72. Jones, P.; Boujenko, N.; Marshall, S. Link E Place: A Guide to Street Planning and Design; Local Transport Today Ltd.: London, UK, 2007; ISBN 978-1-899650-41-5.

(C) 2020 by the authors. Licensee MDPI, Basel, Switzerland. This article is an open access article distributed under the terms and conditions of the Creative Commons Attribution (CC BY) license (http://creativecommons.org/licenses/by/4.0/). 